\title{
REFUGEES IN GERMANY: AMONGST CULTURE OF WELCOME AND XENOPHOBIA
}

\author{
Sophia Marek \\ Social and Cultural Anthropology, Goethe-University Frankfurt \\ $<$ sophia.marek@t-online.de>
}

\begin{abstract}
The refugee crisis in Germany is a part of the European migrant crisis in connection with the immigration of high numbers of people arriving in the European Union (EU) from across the Mediterranean Sea or overland through Southeast Europe. This period reached its'summit in 2015/2016 with over a million protection seekers arriving in Germany.

The high influx of protection seekers in such a short time has caused a social debate in Germany on how to handle the high numbers of immigrants and arrange the political asylum. There are different views on the reception of migrants that range from culture of welcome to xenophobia. This can be observed in the society, where a part of the population gets involved with the refugees' integration, whereas another (increasing) part foments anti-immigrant sentiments. Between those beliefs many different attitudes and behaviours towards refugees can be found.

This article discusses the situation of refugees and asylum seekers in Germany, concerning the divided opinions reaching from a culture of welcome to xenophobia. It addresses the transformation that Germany is currently undergoing and gives several examples on incidents of and against refugees that affect the mindset of the German population.
\end{abstract}

Key words: refugee, refugee crisis, culture of welcome, xenophobia, immigration, right-wing

\section{Introduction}

The refugee crisis in Germany is, as a part of the European migrant crisis, linked to the immigration of high numbers of people arriving in the European Union (EU) from across the Mediterranean Sea or overland through
Southeast Europe. This period reached its' summit in 2015 and 2016 with over a million people who seek protection arriving in Germany. Reasons such as violence, war, discrimination or political prosecution in form of social exclusion because of religious belief, 
political opinion or ethnicity, persuade people to take refuge. In 2018 more than 70 million people have been on the run worldwide (lpb n.d.: Flüchtlinge in Deutschland). The way into the EU often means crossing the Mediterranean Sea is unavoidable. Protection seekers try to pass the ocean under terrible conditions and in unsafe, overloaded boats and dinghies (see figure 1). Many of them die drowning or go missing at sea (Unhcr 2015: 2). The lack of legal routes drives them into the arms of smugglers where refugees, especially women and children, often have to experience abuse, exploitation and human rights violations (Unher 2015: 7). At the ports of entrance, European rescue organisations provide first aid, save refugees from drowning or manage the further procedure.

Article 14 of the United Nations Universal Declaration of Human Rights says that "everyone has the right to seek and to enjoy in other countries asylum from persecution" (United Nations n.d.: Article 14). All foreigners who are in Germany because of humanitarian reasons are protection seekers. Within this generic term, several species exist.

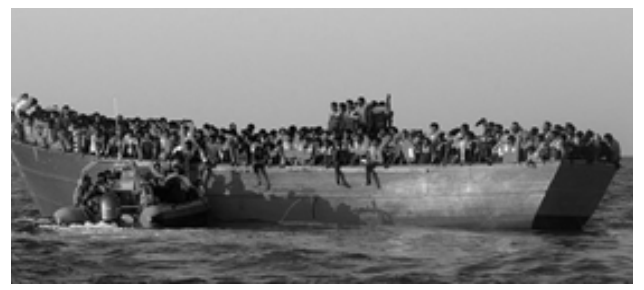

Fig. 1: Rescue of refugees at sea by Giorgos Moutafis and Reuters (2016)
An asylum seeker is a person applying for asylum with an open protection status. A refugee, in contrast, has a right of asylum and an approved protection status. Furthermore, there are protection seekers with a rejected protection status, meaning that the asylum was not granted and that they have to leave Germany and return to their home country. People who rely on their right of asylum have to prove their fulfilment of all conditions in a procedure which can last several months. The main countries of origin are Syria, Irak and Nigeria, as seen on figure 2 (lpb n.d.: Flüchtlinge in Deutschland).

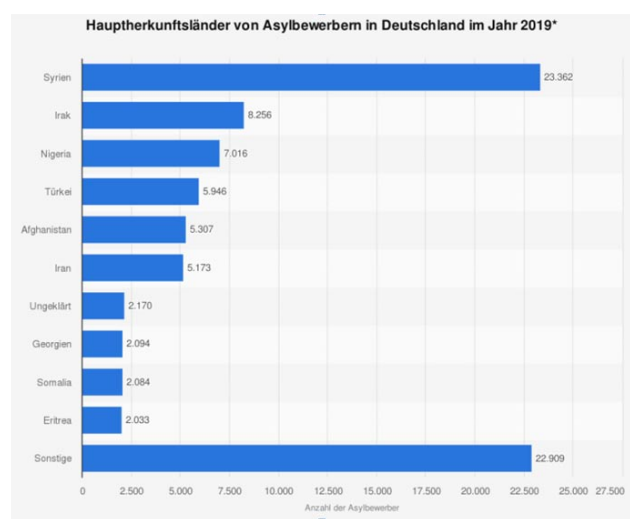

Fig. 2: Main countries of origin of all asylum applicants in Germany 2019 by BAMF Statista (2019)

Why is Germany such a favoured country of immigration? Results of a study in Bavaria that interviewed around 800 refugees show, that peace, political stability, protection and safety are the main reasons to choose Germany. Besides, freedom of religion and a more tolerant environment as 
well as gender equality in a modern society play an important role during the decision-making. Less important is the country's economic strength. Many of the respondents have been highly motivated, wanted to learn German and get a job while living a safe and peaceful life (Englisch 2017: Studie).

\section{Culture of welcome}

Those hopes and dreams that protections seekers wish to find in Germany, oftentimes collide with the ultimately discovered reality. The term "culture of welcome" originated in 2015 with the arrival of 20.000 protection seekers in Munich who have been welcomed by the German population with applause, hugs and gifts. This action showed solidarity and the positive attitude towards protection seekers whose joy and relief can be seen in figure 3 (Große 2019: Deutschland und die Flüchtlinge).

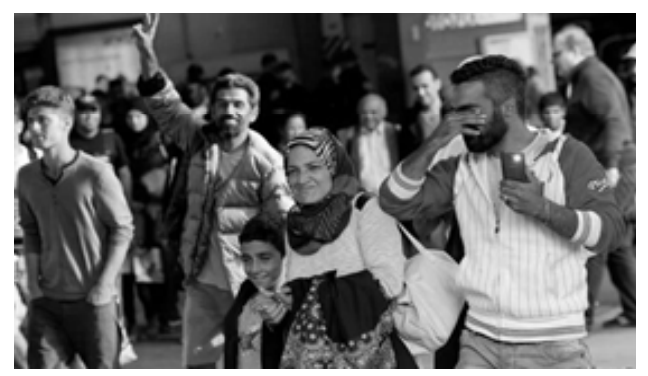

Fig. 3: Joy and relief at the arrival in Munich by picture alliance-dpa (2019)

Voluntary commitment of the population in form of donations, integration assistance, food distribution, children programs or visits to authorities, characterized the time after. The population's majority thinks that people who leave their country because of war and persecution should find refuge in Germany. However, certain concerns about a successful integration, immigration in general, Islam and foreigners exist. This is why many Germans say that immigration has to be limited. In addition it should be mentioned that the media coverage concentrates on marginal groups, in this connection a culture of welcome and xenophobia, although there are many different opinions in Germany (lpb n.d. Flüchtlinge in Deutschland). This leads to the communication of a stereotyped image of protection seekers, which I want to elaborate on now.

\section{Common stereotypes against pro- tection seekers}

Stereotypes complicate the arrival for protection seekers and the work of those who want to help them. They poison the political climate and make factual discussions impossible. However, they do not live up to the complex social reality (Uno Flüchtlingshilfe n.d.: Faktencheck).

First of all, the widespread belief that protection seekers are "all economic migrants and get more money than Germans" should be mentioned. This statement though does not correlate with the reality. The unemployment benefits in Germany called "Hartz IV" are 424 Euro per 
month. Asylum applicants in temporary accommodations get their basic needs, such as meals, clothes, household goods and sanitary products covered as well as a pocket money of 150 Euro per month. Aside from that asylum applicants have limited medical aid and other shortages. People with granted asylum do have the same right to social benefits as German citizens, neither more nor less. Additionally it has to be said that no one takes such a risky and long journey to Germany out of comfort. Protection seekers left their countries because they had no other choice, due to safety reasons and not to profit from the social benefits in Germany (Uno Flüchtlingshilfe n.d.: Faktencheck).

Secondly, many Germans think that "Germany receives the most refugees" but the most refugees stay in their own country. Of the current 70 million protection seekers worldwide, $91 \%$ do not live in Europe. They seek protection in their own country or in Asia and Africa. The belief that Germany or the $\mathrm{EU}$ receives the most refugees is wrong and Eurocentric. In actual fact, the real refugee crisis lies in Bangladesh, South Sudan or in the Democratic Republic of the Congo, to name a few examples. According to the received numbers of protection seekers, Germany is at 5th place worldwide, regardless of its' economic strength, population and political situation (Uno Flüchtlingshilfe n.d.: Faktencheck).

Certain incidents that have been highlighted by the media caused an image that "all protection seekers are criminals". In 2018 8,6 percent of all suspects have been immigrants. Among this term are refugees, protection seekers, people with exceptional leave to remain for humanitarian reasons and illegal immigrants. This number is higher than their part of the total population. The source of a higher crime rate is not caused by their origin or ethnicity though. Many factors have to be considered such as the social structure in which the protection seekers live. More than $60 \%$ of all asylum applicants between 2015 and 2018 have been men, mostly 30 years old and younger. Young men are more willing to take risks. Additionally the circumstances and perspective of protection seekers have to be taken into account. Protection seekers often live in temporary mass accommodations after their arrival in Germany. This situation reinforces discussions and fisticuffs. Lack of prospect, insecurity and frustration, especially when the asylum was rejected, often lead to a higher willingness to carry a risk. Refugees with an approved protection status or granted asylum, on the other hand, commit fewer crimes (Uno Flüchtlingshilfe n.d.: Faktencheck). Lastly, the question "why does every refugee have a mobile phone?" appears more and more. Being a refugee or protection seeker does not mean to be poor. Many of them had 
high education standards and a good degree in their home country. Again it has to be said that they seek refuge in Germany because of violence, war or persecution and not because they were poor. Protection seekers buy phones for their escape and because it is the only way to keep in touch with their families (heute 2017).

Particular occurrences that involved protection seekers influenced the mindset of the German population and have been highlighted by the media. I will explain two of them more detailed.

\section{Sexual assaults at New Year's Eve 2015 in Cologne}

At New Year's Eve 2015, more than 1200 women have been assaulted in various German cities. In Cologne the numbers have been exceedingly high. Around 600 victims were reported. Around 2000 men, many of them with a foreign nationality, were involved in these sexual assaults and robberies in Germany. Many crimes were not reported and not all suspects have been identified. This incident caused a wave of fear among the people in Cologne and Germany in general and cast a slur at protection seekers and refugees (Noack 2016).

"Public confidence in [the] [...] governments' ability to deal with the crisis has rapidly declined" and we have to ask if the "initial calm, goodwill, and even enthusiasm for the new arrivals and welcome culture have given way to growing public anger" (Tausch 2019: 68)? A strengthening of right-wing and populist political parties cannot be denied. Their fear is to lose the German identity and to give way to foreign domination and Islamisation (Rommel 2017: 134). There is not only a radicalised minority but also political parties like "Alternative for Germany" (AfD) who represent such nationalistic and racist opinions and use incidents like in Cologne to confirm their political opinion.

\section{Alternative for Germany (AfD)}

AfD represents identity centred themes such as German merits or core culture, which are threatened by the protection seekers coming to Germany. Especially the German language constitutes a main object of identity (Rommel 2017: 137). AfD politician Höcke once said that many people in Germany "suffer from a lack of symbolic national pride" (Rommel 2017: 137) which is a shame for nation-orientated people. Statements like "Multiculturalism is a threat" and "Islam does not belong to Germany" label Germans with migration background and refugees as "Muslim". Hereby a "Muslim" is a cultural-other or cultural enemy in the German society. The prominent sentence "Germany is no immigration country" degrades all immigrants who live in Germany for a while and shows that they do not belong (Rommel 2017: 137-138). 
The number of radicals in the society rises. The right has already more than 20.000 supporters. Counted are exclusively extremists. This implies that the number of people with xenophobic, anti-Islam and racist thoughts is by far higher. Violence and crimes increase. Especially the so-called "hate crime" against people because of their look, supposed nationality, religion, sexual orientation or social status enjoys great popularity. Besides, a multitude of racist comments can be found in social media platforms. Demonstrations and attacks on refugee accommodations, aid workers or politicians are part of the daily reality in Germany. The frequency of those incidents rises and falls with the increase and decrease of the number of protection seekers arriving in Germany (Jansen 2017).

\section{Incidents in Chemnitz, August 2018}

On August 26th 2018, a 35 year old German man was killed and two others injured in the East German city Chemnitz. Two asylum applicants from Iraq and Syria have been arrested. In the following days, hundreds of protestors have been mobilised by right-wing groups like AfD, Pro Chemnitz or Pegida, to demonstrate on the streets in Chemnitz. The demonstrations, seen on figure 4 , were characterized by antisemitism, racist slander against people with a "foreign look", spread of hatred, Nazi salute and attacks against foreigners, the media and policemen. On the other hand, German bands gave concerts as protest against racism but it can be seen that xenophobia is a part of the everyday life in Germany (Gensing 2018).

\section{Summary}

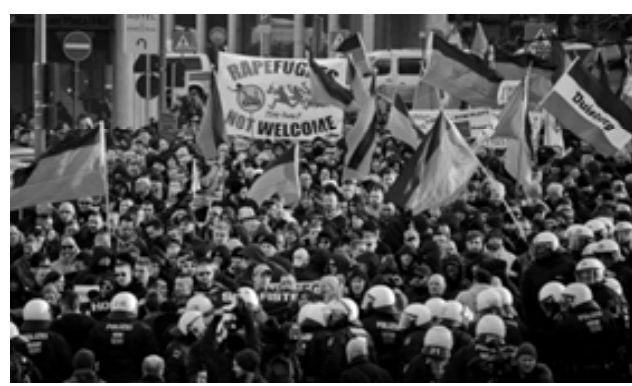

Fig. 4: Demonstrations in Chemnitz by Aljazeera (2018)

Protection seekers are oftentimes generalized as "Muslim", "violent criminal" and "foreigner". Those Eurocentric labels show that little knowledge of the circumstances that persuade someone to leave his or her country and take the risk of a dangerous journey to Europe exist. They also show the little knowledge about Islam in many parts of the German society.

Between the small number of criminal refugees and the high number of motivated refugees who are willing to learn German, get a job and integrate into the society is many times no differentiation made. This generalization fuels the spread of stereotypes that affect the integration of refugees. Many protection seekers are afraid that xenophobic sentiments 
also turn against them and negatively influence their future. They are ashamed of other, criminal protection seekers and convict their crimes as well. The media coverage plays a significant role in the German refugee crisis as a wrong focus that does not always correspond with the reality produces a false image of immigrants and refugees.
Hesitant political decisions concerning the distribution of protection seekers and the asylum process have caused numerous protest voters who turn to political parties like AfD. The "Alternative for Germany" has in many cases become a real alternative.[]

\section{References}

Englisch, Roland (2017): "Studie. Warum Flüchtlinge nach Deutschland kommen". Electronical document: https://www.nordbayern.de/politik/studie-warum-fluchtlingenach-deutschland-kommen-1.6205628 (last accessed: 12.09.2019).

Gensing, Patrick (2018): "Ein Tötungsdelikt und die politischen Folgen". Electronical document: https://www.tagesschau.de/faktenfinder/inland/chronologie-chemnitz-103. html (last accessed: 12.09.2019).

Große, Patrick (2019): "Deutschland und die Flüchtlinge. Wie 2015 das Land veränderte“. Electronical document: https://www.dw.com/de/deutschland-unddie-fl\%C3\%BCchtlinge-wie-2015-das-land-ver\%C3\%A4nderte/a-47459712 (last accessed: 13.09.2019).

Heute (2017): "Die gängigsten Vorurteile gegen Flüchtlinge“. Electronical document: https:// www.heute.at/s/-20835678 (last accessed: 12.09.2019).

Jansen, Frank (2017): "Rechtsextremismus in Deutschland. Rechte Szene wächst und wird militanter". Electronical document: https://www.tagesspiegel.de/ politik/rechtsextremismus-in-deutschland-rechte-szene-waechst-und-wirdmilitanter/19299078.html (last accessed: 14.09.2019).

Lpb (n.d.): "Flüchtlinge und Schutzsuchende in Deutschland". Electronical document: https:// www.lpb-bw.de/fluechtlingsproblematik.html\#c51007 (last accessed: 12.09.2019).

Noack, Rick (2016): "2000 Men Sexually Assaulted 1200 Women at Cologne New Year's Eve Party". Electronical document: https://www.independent.co.uk/news/world/europe/ cologne-new-years-eve-mass-sex-attacks-leaked-document-a7130476.html (last accessed: 14.09.2019).

Rommel, Inken (2017): "We are the People. Refugee-Crisis and the Drag-Effects of Social Habitus in German Society". Historical Social Research 42 (4): 133-154.

Tausch, Arno (2019): "Migration from the Muslim World to the West". Jewish Political Studies Review 30 (1/2): 65-225.

UNHCR (2015): "The Sea Route to Europe. The Mediterranean Passage in the Age of Refugees". Electronical document: https://www.unhcr.org/protection/operations/5592bd059/searoute-europe-mediterranean-passage-age-refugees.html (last accessed: 15.09.2019).

United Nations (n.d.): “Universal Declaration of Human Rights". Electronical document: https:// www.un.org/en/universal-declaration-human-rights/ (last accessed: 13.09.2019).

UNO Flüchtlingshilfe (n.d.): "Vorurteile gegen Flüchtlinge auf dem Prüfstand". Electronical Document: https://www.uno-fluechtlingshilfe.de/informieren/faktencheck/ (last accessed: 13.09.2019). 